\title{
Tree Dominated Agriculture for Environmental Services and Sustainable Livelihoods in Sri Lanka
}

\author{
Melvani K.* \\ Charles Darwin University, Australia \\ *neosynth@sltnet.lk
}

\begin{abstract}
Rapidly dwindling forest cover has resulted in increased efforts in reclamation, rehabilitationand restoration in Sri Lanka. Forest reclamationis carried out by the State through the planting of exotic tree monocultures. Rehabilitation is undertaken by State and Non Government Organisations (NGO) such as Neo Synthesis Research Centre (NSRC) through community based forestry programs. NSRC takes a watershed perspective in rehabilitation where activities include the conversion of degraded homegardens to forest gardens. Multi functional landscape designs are used that mimic the architectural structure and ecological function of the closest natural forest. They usenative and exotic species since the design aims at soil and water conservation, production of food, timber, medicine, fodder, fuelwood and recreating habitat. Riparian areas adjacent to the gardens are restored using only native species of plants, as are the buffer zones on the boundaries of gardens that abut natural forest. This paper evaluates some landscape level rehabilitation efforts undertaken by NSRC.
\end{abstract}

48 chena lands were converted to forest gardensin the Maragala Oya watershed. A comparative study of birddetections, assemblages and richness was carried out in forest and forest gardens. While the forest gardens had a greater number of species, the forest plots had a higher number of endemics. Farmer income had increased with pepper as the dominant crop.

The phytoremediation of ground water was undertaken in the Kalpitiya Peninsula. Native vegetation was established around adrinking water well contaminated with nitrates and nitrites and the surroundings subject to organic agriculture. Canopies formed above ground and a dense root mat below after which water was tested monthly for 5 years. Analysis of data revealed a reduction in nitrates and electrical conductivity and a return to potability.

Tsunami affected lands were rehabilitated in Kalmunai. 250 homegardens were re-established with a focus on tree dominant agriculture, a $3 \mathrm{~km}$ coastal forest to buffer imminent sea level rise was established andthe microwatersheds of 1,001 wells were planted to effect phytoremediation. Food security was enhanced where the value of the vegetables cultivated was $35 \%$ of total income. The 9 year coastal forest is now mature and there are trees around wells.

Part of a privately owned, degraded land in Serukelewas restored to forestand another part converted to regenerative agriculture. Phenomenal growth was witnessed in ten years where more than $60 \%$ shade has been established. The habitat recreated was tested for mammal assemblages. Continuous monitoring revealed that of the 41 species found in the Wilpattu National Park, 21 or $50 \%$ were observed on Munamal Estate.

Keywords: Tree dominated agriculture 